\title{
Integrating Biochemical, Morpho-physiological, Nutritional, and Productive Responses to Cd Accumulation in Massai Grass Employed in Phytoremediation
}

\author{
Flávio Henrique Silveira Rabêlo (D) \\ Rafael de Andrade Moral · José Lavres
}

Received: 7 January 2019 / Accepted: 18 April 2019/Published online: 3 May 2019

(C) Springer Nature Switzerland AG 2019

\begin{abstract}
Cadmium (Cd) phytoextraction efficiency basically depends on $\mathrm{Cd}$ accumulation in their tissues. Thus, our aim in this study was to select biochemical, morphophysiological, nutritional, and productive responses associated to $\mathrm{Cd}$ accumulation in the roots, stems and sheaths, and leaf blades of Panicum maximum cv. Massai (Massai grass), using the random forests analysis. Massai grass was exposed to combinations of three sulfur (S) concentrations $\left(0.1,1.9\right.$, and $\left.3.7 \mathrm{mmol} \mathrm{L}^{-1}\right)$ and two $\mathrm{Cd}$ concentrations $\left(0.0\right.$ and $\left.0.1 \mathrm{mmol} \mathrm{L}^{-1}\right)$ in nutrient solutions. The dry biomass production of Massai grass exposed to $\mathrm{Cd}$ decreased by around $50 \%$ in relation to control. However, there were no visual symptoms of Cd toxicity in the shoot of this plant, even with Cd concentrations in their shoot exceeding $100 \mathrm{mg} \mathrm{kg}^{-1} \mathrm{DW}$. The lowest dry biomass production of the plants exposed to $\mathrm{Cd}$ combined with the absence of visual symptoms of Cd toxicity indicates us that Massai grass is a bioindicator plant that can greatly cope with the Cd-induced stress, but in a little bit different way from other plants. Antioxidant enzymes apparently are not essential for Massai grass cope with
\end{abstract}

Electronic supplementary material The online version of this article (https://doi.org/10.1007/s11270-019-4167-0) contains supplementary material, which is available to authorized users.

F. H. S. Rabêlo $(\bowtie) \cdot$ J. Lavres

Center for Nuclear Energy in Agriculture, University of São Paulo, Piracicaba, Brazil

e-mail: flaviohsr.agro@usp.br

R. de Andrade Moral

Department of Mathematics and Statistics, Maynooth University, Maynooth, Ireland
Cd-induced stress, differently of other mechanisms (e.g., higher synthesis of thiol compounds and amino acids involved on reactive oxygen species (ROS) scavenging and Cd chelation). Probably, the plant responses that most explained $\mathrm{Cd}$ accumulation in Massai grass can be used to identify grasses with high capacity to accumulate $\mathrm{Cd}$ in phytoremediation programs with this group of plants.

Keywords Cd accumulation $\cdot$ Forage grasses $\cdot$ Nonhyperaccumulator $\cdot$ Poaceae $\cdot$ Random forests

\section{Introduction}

Cadmium (Cd) concentration in the environment has been increased in several countries due mainly to anthropogenic activities (represents more than $90 \%$ of $\mathrm{Cd}$ added to the environment), such as the inappropriate disposal of municipal and industrial wastes and the use of fertilizers (e.g., phosphate fertilizer) of poor quality (Khan et al. 2017). It is a serious socio-environmental problem since $\mathrm{Cd}$ is one of the most toxic heavy metals present in the environment, and it can be taken up by plants and thereby enter into the human food chain (Nawrot et al. 2010). Clemens et al. (2013) reported that Cd intake by humans is above the limits recommended by the US Agency for Toxic Substances and Disease Registry (ATSDR) and the European Food Safety Authority (EFSA). It is important to highlight that $\mathrm{Cd}$ can cause a series of diseases in the humans such as pulmonary emphysema and cancer (Nawrot et al. 2010). Therefore, it is indispensable to decrease $\mathrm{Cd}$ concentration in the environment. There 
are many strategies to decrease $\mathrm{Cd}$ concentration in the environment such as excavation, landfill, and leaching (Khan et al. 2017), but phytoextraction displays the lowest environmental impact and costs and as such is often regarded as the most socially acceptable strategy (Vangronsveld et al. 2009). On the other hand, only a limited number of plants can uptake high amounts of $\mathrm{Cd}$ (hyperaccumulators) due to its toxicity (Reeves et al. 2017), and all these plants present low biomass production and slow growth, which decreases $\mathrm{Cd}$ phytoextraction efficiency (Vangronsveld et al. 2009). Therefore, plants that present high biomass production and fast growth, such as forage grasses, can be a good alternative for $\mathrm{Cd}$ phytoextraction in relation to use of the already known Cd hyperaccumulators (Rabêlo and Borgo 2016).

Besides the high biomass production (often higher than $20 \mathrm{t} \mathrm{DW} \mathrm{ha}^{-1}$ year $^{-1}$ ) and fast growth, the most part of the forage grasses have an extensive root system, low requirements on soil fertility, adaptation to soil and climatic adversities, and successive emissions of shoot apical meristem after the harvest of shoots (Rabêlo et al. 2018a). These characteristics are desirable for phytoextraction (Vangronsveld et al. 2009), mainly when associated with $\mathrm{Cd}$ tolerance. Thus, several studies with forage grasses have been conducted to assess its $\mathrm{Cd}$ accumulation capacity and its phytoextraction potential (Wang et al. 2013; Marzban et al. 2017; Rabêlo et al. 2017a, b, c, 2018b, c, d). Among the forage grasses studied, Panicum maximum cv. Massai (Massai grass) has been outstanding for surviving at concentrations of $0.1 \mathrm{mmol} \mathrm{L}^{-1} \mathrm{Cd}$ in the nutrient solution without showing visible symptoms of Cd toxicity in the shoots (e.g., chlorosis), even with $\mathrm{Cd}$ concentrations in their shoot exceeding $100 \mathrm{mg} \mathrm{kg}^{-1} \mathrm{DW}$, which suggests that this plant species can be used for Cd phytoextraction (Rabêlo et al. 2017c, 2018b, c, d). In this sense, Massai grass can be used as a model plant to identify the main plant responses that are associated to $\mathrm{Cd}$ accumulation in forage grasses. We know that many factors, such as the nutritional status of the plant and the capacity to translocate $\mathrm{Cd}$ from roots to shoots, synthesize $\mathrm{Cd}$ chelators (e.g., glutathione (GSH) and phytochelatins (PCs)) and mitigate the oxidative stress $\mathrm{Cd}$-induced are associated to $\mathrm{Cd}$ accumulation (Clemens 2006; Gallego et al. 2012). However, we do not know which of these plant responses are in fact more related to $\mathrm{Cd}$ accumulation in forage grasses (Rabêlo et al. 2018a). Thus, it is essential to identify the main plant responses related to $\mathrm{Cd}$ accumulation to select forage grasses with real capacity for $\mathrm{Cd}$ phytoextraction.
Some recent studies (Yu et al. 2016; Redovniković et al. 2017) have used a statistical method based on random forests, a powerful statistical classifier (Breiman 2001), in order to determine the most important variables affecting $\mathrm{Cd}$ accumulation and plant growth under $\mathrm{Cd}$-induced stress. This method presents high classification accuracy, the ability to characterize complex interactions among variables and to determine variable importance (Breiman 2001). In this sense, we used the published data from our previous studies in hydroponics (Rabêlo et al. 2018b, c, d) to assay nutritional status (Rabêlo et al. 2018b), synthesis of Cd chelators (e.g., PCs and histidine) (Rabêlo et al. 2018c), and activities of antioxidant (enzymatic and non-enzymatic) and photosynthetic systems (Rabêlo et al. 2018d) of Massai grass in order to obtain several plant responses related to $\mathrm{Cd}$ accumulation to conduct the current study. We chose $\mathrm{Cd}$ accumulation as the variable response since $\mathrm{Cd}$ phytoextraction efficiency depends on the $\mathrm{Cd}$ concentration in the harvestable plant parts and biomass production $(\mathrm{Cd}$ accumulation $=\mathrm{Cd}$ concentration $\times$ biomass production) (Vangronsveld et al. 2009). Therefore, our aim with this study was to select the plant responses most associated to $\mathrm{Cd}$ accumulation in the roots, stems and sheaths, and leaf blades of Massai grass, using random forests, in order to select plant responses that can be used to identify Cd-tolerant forage grasses in possible phytoremediation programs with this group of plants.

\section{Materials and Methods}

\subsection{Treatments and Experimental Design}

Panicum maximum Jacq. cv. Massai plants were grown in a hydroponics system using 2.2-L plastic pots containing $2 \mathrm{~L}$ of nutrient solution arranged in a greenhouse $\left(22^{\circ} 42^{\prime}\right.$ south latitude and $47^{\circ} 38^{\prime}$ west longitude). The treatments were represented by combinations of three sulfur $(\mathrm{S})$ concentrations $\left(0.1,1.9\right.$, and $\left.3.7 \mathrm{mmol} \mathrm{L}^{-1}\right)$ and two $\mathrm{Cd}$ concentrations $\left(0.0\right.$ and $\left.0.1 \mathrm{mmol} \mathrm{L}^{-1}\right)$, in nutrient solutions modified from the solution of Hoagland and Arnon (1950). The control treatment is represented by $0.0 \mathrm{mmol} \mathrm{L}^{-1} \mathrm{Cd}$ and $1.9 \mathrm{mmol} \mathrm{L}^{-1} \mathrm{~S}$, since $1.9 \mathrm{mmol} \mathrm{L}^{-1} \mathrm{~S}$ is the concentration of $\mathrm{S}$ indicated for better forage grasses growth under $\mathrm{Cd}$ exposure (Rabêlo et al. 2017a, b). It is important to mention that $\mathrm{S}$ concentrations were not considered as a factor during 
the process of variable selection. Thus, the effect of S on plant responses to $\mathrm{Cd}$ was briefly discussed in this study. The composition and chemical speciation (Cd availability higher than $85 \%$ in all treatments) of nutrient solution used in the study is shown in Table 1 and Supplemental file 1 , respectively. The experiment was set up in a randomized complete block design (Montgomery 1984), with four blocks, each consisting of six pots, representing the six combinations between the concentrations of $\mathrm{S}$ and $\mathrm{Cd}$.

\subsection{Growth Conditions and Harvest of Massai Grass}

Seeds were sown in a tray containing expanded vermiculite, which was irrigated with deionized water in the first 14 days and nutrient solution modified in order to provide $0.1 \mathrm{mmol} \mathrm{L}^{-1} \mathrm{~S}$ (diluted to $25 \%$ ionic strength) over the following 9 days. After 23 days, five seedlings $( \pm 10 \mathrm{~cm}$ height) were transplanted to each pot containing the undiluted nutrient solutions (100\% ionic strength) modified to provide one of the three different experimental $\mathrm{S}$ concentrations for a further 21 days. After this period, modified nutrient solutions were provided to obtain different $\mathrm{S}$ and $\mathrm{Cd}$ concentrations (100\% ionic strength) during 9 days. Solutions were replaced every week and remained constantly aerated. The average temperature in the greenhouse was $30.5 \pm 3.1{ }^{\circ} \mathrm{C}$ and the relative

Table 1 Volume of stock solutions used in the preparation of the nutrient solutions for the Massai grass hydroponic cultures

\begin{tabular}{|c|c|c|c|c|c|c|}
\hline \multirow{2}{*}{$\begin{array}{l}\mathrm{S}\left(\mathrm{mmol} \mathrm{L}^{-1}\right) \\
\mathrm{Cd}\left(\mathrm{mmol} \mathrm{L}^{-1}\right) \\
\text { Stock solution }\end{array}$} & & & & $\begin{array}{l}1.9 \\
0.1\end{array}$ & $\begin{array}{l}3.7 \\
0.0\end{array}$ & $\begin{array}{l}3.7 \\
0.1\end{array}$ \\
\hline & \multicolumn{6}{|c|}{ Volume $\left(\mathrm{mL} \mathrm{L}^{-1}\right)$} \\
\hline $\mathrm{CdCl}_{2}\left(0.1 \mathrm{~mol} \mathrm{~L}^{-1}\right)$ & 0 & 1 & 0 & 1 & 0 & 1 \\
\hline $\mathrm{KH}_{2} \mathrm{PO}_{4}\left(1 \mathrm{~mol} \mathrm{~L}^{-1}\right)$ & 1 & 1 & 1 & 1 & 1 & 1 \\
\hline $\mathrm{NH}_{4} \mathrm{NO}_{3}\left(1 \mathrm{~mol} \mathrm{~L}^{-1}\right)$ & 4.5 & 4.5 & 4.5 & 4.5 & 4.5 & 4.5 \\
\hline $\mathrm{KNO}_{3}\left(1 \mathrm{~mol} \mathrm{~L}^{-1}\right)$ & 6 & 6 & 6 & 6 & 6 & 6 \\
\hline $\mathrm{KCl}\left(1 \mathrm{~mol} \mathrm{~L}^{-1}\right)$ & 1 & 1 & 1 & 1 & 1 & 1 \\
\hline $\mathrm{MgSO}_{4} \cdot 7 \mathrm{H}_{2} \mathrm{O}\left(1 \mathrm{~mol} \mathrm{~L}^{-1}\right)$ & 0.1 & 0.1 & 1.9 & 1.9 & 2 & 2 \\
\hline $\mathrm{MgCl}_{2} \cdot 6 \mathrm{H}_{2} \mathrm{O}\left(1 \mathrm{~mol} \mathrm{~L}^{-1}\right)$ & 1.9 & 1.9 & 0.1 & 0.1 & - & - \\
\hline $\mathrm{CaSO}_{4} \cdot 2 \mathrm{H}_{2} \mathrm{O}\left(0.01 \mathrm{~mol} \mathrm{~L}^{-1}\right)$ & - & - & - & - & 170 & 170 \\
\hline $\mathrm{CaCl}_{2}\left(1 \mathrm{~mol} \mathrm{~L}^{-1}\right)$ & 5 & 5 & 5 & 5 & 3.3 & 3.3 \\
\hline Micronutrients $-\mathrm{Fe}^{1}$ & 1 & 1 & 1 & 1 & 1 & 1 \\
\hline $\mathrm{Fe}(\mathrm{III})-\mathrm{EDTA}^{2}$ & 1 & 1 & 1 & 1 & 1 & 1 \\
\hline
\end{tabular}

${ }^{1}$ Composition of micronutrient solution $\left(\mu \mathrm{mol} \mathrm{L}^{-1}\right): \mathrm{KCl}=50$; $\mathrm{H}_{3} \mathrm{BO}_{3}=25 ; \mathrm{MnSO}_{4} \cdot \mathrm{H}_{2} \mathrm{O}=2 ; \mathrm{ZnSO}_{4} \cdot 7 \mathrm{H}_{2} \mathrm{O}=2 ; \mathrm{CuSO}_{4} \cdot 5 \mathrm{H}_{2} \mathrm{O}=$ $0.5 ; \mathrm{H}_{2} \mathrm{MoO}_{4}\left(85 \% \mathrm{MoO}_{3}\right)=0.5$

${ }^{2} \mathrm{Fe}(\mathrm{III})-\mathrm{EDTA}=100 \mu \mathrm{mol} \mathrm{L}{ }^{-1}$ humidity of the air was $60.5 \pm 10.7 \%$ (Supplemental file 2). After 9 days of exposure to $\mathrm{S}$ and Cd concentrations, the plants were harvested and analyzed.

\subsection{Determination of Dry Biomass Production}

The dry biomass production was obtained after weighing the plant material, which remained in a forced air ventilation oven at $60{ }^{\circ} \mathrm{C}$ for $72 \mathrm{~h}$.

\subsection{Determination of $\mathrm{Cd}$ Concentration}

After drying in a forced air ventilation oven at $60{ }^{\circ} \mathrm{C}$ during $72 \mathrm{~h}$, plant material was ground in a Wiley-type mill. Cadmium concentrations were determined after nitric-perchloric digestion $\left(\mathrm{HNO}_{3} \quad 65 \%\right.$ and $\mathrm{HClO}_{4}$ $70 \%$ ), by inductively coupled plasma optical emission spectrometry (ICP-OES, iCAP 7000 SERIES, ThermoScientific, Waltham, USA), as described by Rabêlo et al. (2018b).

\subsection{Variables/Plant Responses Analyzed \\ During the Study (Collected from Previously Published Studies)}

During the last day of exposure of Massai grass to combinations of $\mathrm{S}$ and $\mathrm{Cd}$, the non-destructive analyses were performed to evaluate the effect of the treatments on the photosynthetic and some morphological parameters of the plants. After these non-destructive analyses, Massai grass was collected and separated into roots, stems and sheaths, and leaf blades to perform the destructive analyses to evaluate the nutritional, metabolic, antioxidant, productive, and thiolic parameters. All variables/plant responses analyzed before, during, or after the plant harvest and used in the random forests analysis are described in the last column of the Table 2. The methods used to determine the variables/plant responses are described in Supplemental file 3. All the quantitative results obtained from Rabêlo et al. (2018b, c, d), which are described in the last column of the Table 2, were used in the statistical analysis.

\subsection{Data Used and Statistical Analysis}

All data used in the current study to select the variables that are more associated to $\mathrm{Cd}$ accumulation in the roots, stems and sheaths, and leaf blades of Massai grass were extracted from Rabêlo et al. (2018b, c, d). Data of dry 
Table 2 Description of the variables/plant responses analyzed in different tissues of Massai grass supplied with $\mathrm{S}(0.1$, 1.9 , and $\left.3.7 \mathrm{mmol} \mathrm{L}^{-1}\right)$ and exposed to $\mathrm{Cd}\left(0.0\right.$ and $\left.0.1 \mathrm{mmol} \mathrm{L}^{-1}\right)$, and then used in the random forests analysis

\begin{tabular}{|c|c|c|c|}
\hline $\begin{array}{l}\text { Plant } \\
\text { tissue }\end{array}$ & Parameter & $\begin{array}{l}\text { Type of } \\
\text { analysis }\end{array}$ & Variables/plant responses analyzed \\
\hline \multirow[t]{3}{*}{$\begin{array}{l}\text { Leaf } \\
\text { blades }\end{array}$} & Nutritional & Destructive & $\begin{array}{l}\mathrm{N}, \mathrm{P}, \mathrm{K}, \mathrm{Ca}, \mathrm{Mg}, \mathrm{S}, \mathrm{Cu}, \mathrm{Fe}, \mathrm{Mn}, \mathrm{Zn} \text {, and } \mathrm{Cd} \text { concentrations; } \mathrm{N}, \mathrm{P}, \mathrm{K}, \mathrm{Ca}, \mathrm{Mg}, \mathrm{S} \text {, } \\
\mathrm{Cu}, \mathrm{Fe}, \mathrm{Mn}, \mathrm{Zn} \text {, and } \mathrm{Cd} \text { accumulations; Cd translocation factor }\end{array}$ \\
\hline & Metabolic & Destructive & $\begin{array}{l}\text { Citrate, fumarate, isocitrate, itaconate, } \alpha \text {-ketoglutarate, lactate, malate, } \\
\text { malonate, oxalate, oxaloacetate, succinate, tartrate, cellobiose, erythritol, } \\
\text { fructose, fucose, galactinol, galactitol, glucose, glucose-6-phosphate, } \\
\text { glycerate, idose, maltose, raffinose, rhamnose, ribose, sorbose, sucrose, } \\
\text { talose, trehalose, xylitol, xylose, 5-oxoproline, alanine, asparagine, aspartate, } \\
\text { ß-alanine, cysteine, glutamate, glutamine, glycine, histidine, homoserine, } \\
\text { isoleucine, leucine, L-proline, lysine, methionine, norleucine, O-acetylserine, } \\
\text { ornithine, phenylalanine, proline, serine, threonine, tryptophan, tyrosine, } \\
\text { valine, 4-aminobutanoate, benzoate, cis-aconitate, gluconate, glycerol, } \\
\text { putrescine, pyruvate, shikimate, glycerol 3-phosphate, sinapate, spermidine }\end{array}$ \\
\hline & Antioxidant & Destructive & $\begin{array}{l}\text { Hydrogen peroxide }\left(\mathrm{H}_{2} \mathrm{O}_{2}\right) \text {, malondialdehyde (MDA), superoxide dismutase } \\
\text { (SOD), Mn-SOD, Cu/Zn-SOD, catalase (CAT), glutathione-S-transferase } \\
\text { (GST), guaiacol peroxidase (GPOX), glutathione reductase (GR), ascorbate } \\
\text { peroxidase (APX), reduced (GSH), oxidized (GSSG) and total glutathione } \\
\text { (GSH + GSSG), redox state (GSH/GSSG), dehydroascorbate (DHA), gene } \\
\text { expression (GSH1, PCS2, CSD2, CSD3, FSD2, MSD1, APX1, GR1, GR2, } \\
C A T 1 \text {, and CAT2) }\end{array}$ \\
\hline
\end{tabular}

Photosynthetic

Morphological—productive Destructive

Thiolic

Stems and Nutritional sheaths

Metabolic

Antioxidant

Destructive

Morphological—productive Destructive Thiolic

Destructive

Roots

Nutritional

Destructive

Metabolic

Destructive
Destructive

Destructive

Destructive
Chlorophyll concentration (SPAD), net photosynthetic rate $(A)$, stomatal conductance $\left(g_{\mathrm{s}}\right)$, internal carbon concentration $\left(c_{\mathrm{i}}\right)$, carboxylation efficiency $(k)$, instantaneous water use efficiency (WUE), intrinsic water use efficiency $\left(\mathrm{WUE}_{\mathrm{i}}\right)$

Leaves number, leaf area, specific leaf area, dry biomass production, growth inhibition

Homoglutathione, h- $\mathrm{PC}_{4}, \mathrm{PC}_{6}$, total phytochelatins, total non-protein thiols

$\mathrm{N}, \mathrm{P}, \mathrm{K}, \mathrm{Ca}, \mathrm{Mg}, \mathrm{S}, \mathrm{Cu}, \mathrm{Fe}, \mathrm{Mn}, \mathrm{Zn}$, and Cd concentrations; N, P, K, Ca, Mg, S, $\mathrm{Cu}, \mathrm{Fe}, \mathrm{Mn}, \mathrm{Zn}$, and $\mathrm{Cd}$ accumulations; Cd translocation factor

Citrate, fumarate, isocitrate, itaconate, $\alpha$-ketoglutarate, lactate, malate, malonate, oxalate, oxaloacetate, succinate, tartrate, cellobiose, fructose, fucose, galactinol, glucose, glucose-6-phosphate, glycerate, raffinose, rhamnose, ribose, sorbose, sucrose, talose, trehalose, xylitol, xylose, 5-oxoproline, alanine, arginine, asparagine, aspartate, $\beta$-alanine, citrulline, glutamate, glutamine, glycine, histidine, isoleucine, leucine, L-proline, lysine, methionine, norleucine, O-acetylserine, ornithine, phenylalanine, proline, serine, threonine, tryptophan, tyrosine, valine, 4-aminobutanoate, benzoate, cis-aconitate, glycerol, glycerol 3-phosphate, putrescine, pyruvate, shikimate, spermidine

Hydrogen peroxide $\left(\mathrm{H}_{2} \mathrm{O}_{2}\right)$, malondialdehyde (MDA), superoxide dismutase (SOD), Mn-SOD, $\mathrm{Cu} / \mathrm{Zn}-\mathrm{SOD}$, catalase (CAT), glutathione-S-transferase (GST), guaiacol peroxidase (GPOX), glutathione reductase (GR), ascorbate peroxidase (APX), reduced (GSH), oxidized (GSSG), and total glutathione $(\mathrm{GSH}+\mathrm{GSSG})$, redox state $(\mathrm{GSH} / \mathrm{GSSG})$, dehydroascorbate (DHA)

Tillers number, dry biomass production, growth inhibition

h- $\mathrm{PC}_{2}$, cys- $\mathrm{PC}_{2}, \mathrm{PC}_{3}$, h- $\mathrm{PC}_{3}$, cys- $\mathrm{PC}_{3}$, des Gly- $\mathrm{PC}_{4}, \mathrm{~h}-\mathrm{PC}_{4}, \mathrm{PC}_{5}, \mathrm{PC}_{6}$, Total phytochelatins, total non-protein thiols

$\mathrm{N}, \mathrm{P}, \mathrm{K}, \mathrm{Ca}, \mathrm{Mg}, \mathrm{S}, \mathrm{Cu}, \mathrm{Fe}, \mathrm{Mn}, \mathrm{Zn}$, and Cd concentrations; N, P, K, Ca, Mg, S, $\mathrm{Cu}, \mathrm{Fe}, \mathrm{Mn}, \mathrm{Zn}$, and $\mathrm{Cd}$ accumulations

Citrate, fumarate, isocitrate, $\alpha$-ketoglutarate, lactate, malate, malonate, oxalate, oxaloacetate, succinate, tartrate, cellobiose, fructose,

fructose-1,6-diphosphate, fucose, galactinol, glucose, glucose-6-phosphate, 
Table 2 (continued)

\begin{tabular}{|c|c|c|c|}
\hline $\begin{array}{l}\text { Plant } \\
\text { tissue }\end{array}$ & Parameter & $\begin{array}{l}\text { Type of } \\
\text { analysis }\end{array}$ & Variables/plant responses analyzed \\
\hline
\end{tabular}

\begin{tabular}{|c|c|c|}
\hline & & $\begin{array}{l}\text { glycerate, gulose, lyxose, mannose, raffinose, rhamnose, ribose, sorbose, } \\
\text { sucrose, talose, trehalose, xylitol, xylose, 5-oxoproline, alanine, arginine, } \\
\text { asparagine, aspartate, ß-alanine, citrulline, cysteine, glutamate, glutamine, } \\
\text { glycine, histidine, isoleucine, leucine, L-proline, lysine, methionine, } \\
\text { o-acetylserine, ornithine, phenylalanine, proline, serine, threonine, } \\
\text { tryptophan, tyrosine, valine, 4-aminobutanoate, benzoate, cis-aconitate, } \\
\text { gluconate, glycerol, glycerol 3-phosphate, putrescine, pyruvate, shikimate }\end{array}$ \\
\hline Antioxidant & Destructive & $\begin{array}{l}\text { Hydrogen peroxide }\left(\mathrm{H}_{2} \mathrm{O}_{2}\right) \text {, malondialdehyde (MDA), superoxide dismutase } \\
\text { (SOD), Mn-SOD, Cu/Zn-SOD, catalase (CAT), glutathione-S-transferase } \\
\text { (GST), guaiacol peroxidase (GPOX), glutathione reductase (GR), ascorbate } \\
\text { peroxidase (APX), reduced (GSH), oxidized (GSSG) and total glutathione } \\
\text { (GSH + GSSG), redox state (GSH/GSSG), dehydroascorbate (DHA) }\end{array}$ \\
\hline Morphological - productive & Destructive & $\begin{array}{l}\text { Root length, root surface, tolerance index (TI) to } \mathrm{Cd} \text {, dry biomass production, } \\
\text { growth inhibition }\end{array}$ \\
\hline Thiolic & Destructive & $\begin{array}{l}\mathrm{PC}_{2} \text {, des } \mathrm{Gly}-\mathrm{PC}_{2}, \mathrm{~h}-\mathrm{PC}_{2} \text {, cys- } \mathrm{PC}_{2}, \mathrm{PC}_{3}, \mathrm{~h}-\mathrm{PC}_{3}, \mathrm{PC}_{4} \text {, des } \mathrm{Gly}-\mathrm{PC}_{4} \text {, total } \\
\text { phytochelatins, total non-protein thiols }\end{array}$ \\
\hline
\end{tabular}

$\overline{\left.\text { h- } \mathrm{PC}_{(2-4)}=\text { homophytochelatin; } \mathrm{PC}_{(2-6)}=\text { phytochelatin; cys- } \mathrm{PC}_{(2-3)}=\text { isoforms of phytochelatin; des } \mathrm{Gly}_{-} \mathrm{PC}_{(2} \text { and } 4\right)=\text { desglycine }}$ phytochelatins

biomass production and $\mathrm{Cd}$ concentration presented in this study were analyzed using analysis of variance ( $F$ test) and multiple comparisons were performed using Tukey test $(p \leq 0.05)$ using the Statistical Analysis System v. 9.2 (SAS Institute 2008). Random forests were fitted to the $\mathrm{Cd}$ accumulation response variable, using all other variables (Table 2) as possible predictors, using 2000 trees and 20 randomly sampled candidate variables at each split. Moreover, random forests were fitted using only variables within each stratum (Breiman 2001). When the predictor presented missing values, multiple imputation was performed based on a linear regression model including the effects of block, dose of $\mathrm{Cd}$, dose of $\mathrm{S}$, and the interaction between dose of $\mathrm{Cd}$ and dose of S. The prediction accuracy was checked by making simple plots of predicted versus observed values. Then, the 10 most important predictors were selected such that their removal from the regression tree would yield the larger increase in the mean squared error (MSE). This quantity is calculated as:

$\operatorname{MSE}=\frac{1}{n} \sum_{i=1}^{n}\left(y_{i}-\hat{y}_{i}\right)^{2}$

where $n$ is the sample size, $y_{i}$ is the $i$ th observation, and $\hat{y}_{i}$ is the predicted value for the $i$ th observation. When the percentage of increase in the MSE (\%Inc MSE) for an explanatory variable is high, this means that the quality of prediction becomes poor when this variable is removed from the model; i.e., this variable is important to explain the response. All procedures were performed using the $\mathrm{R}$ software (R Core Team 2017; see R codes description in Supplemental file 4). Later, Pearson's correlation studies were performed among $\mathrm{Cd}$ accumulation and the variables selected from random forests analysis for each tissue of Massai grass using the Statistical Analysis System v. 9.2 (SAS Institute 2008).

\section{Results}

3.1 Dry Biomass Production, Cd Concentration, and Symptoms of Cd Toxicity in the Shoots of Massai Grass

The highest dry biomass production in the leaf blades (Fig. 1(A)), stems and sheaths (Fig. 1(B)), and roots (Fig. 1(C)) were observed in $\mathrm{Cd}$ absence when Massai grass was supplied with $1.9 \mathrm{mmol} \mathrm{L}^{-1} \mathrm{~S}$. When Massai grass was exposed to $\mathrm{Cd}$, there was no effect of $\mathrm{S}$ supply $(p>0.05)$ on dry biomass production (Fig. 1(A-C)). Regardless of the dry biomass production, $\mathrm{Cd}$ concentration was higher than $100 \mathrm{mg} \mathrm{kg}^{-1} \mathrm{DW}$ in all tissues of Massai grass (Fig. 1(D-F)). In the leaf blades, the highest $\mathrm{Cd}$ concentration was observed in plants supplied with $0.1 \mathrm{mmol} \mathrm{L}^{-1} \mathrm{~S}$ (Fig. 1(D)), while in the stems and sheaths, the $\mathrm{S}$ supply of $3.7 \mathrm{mmol} \mathrm{L}^{-1}$ resulted in the highest $\mathrm{Cd}$ 
concentration (Fig. 1(E)). There was no effect of S supply $(p>0.05)$ on Cd concentration in the roots (Fig. 1(F)), which was the tissue with the highest $\mathrm{Cd}$ concentration (> $400 \mathrm{mg} \mathrm{kg}^{-1} \mathrm{DW}$ ). Although the dry biomass production of Massai grass exposed to $\mathrm{Cd}$ has been decreased (Fig. 1(A-C)) and the Cd concentrations in all tissues of this plant has been higher than $100 \mathrm{mg} \mathrm{kg}^{-1} \mathrm{DW}$ (Fig. 1(D-F)), there was no visual symptoms of Cd toxicity in the shoot of these plants (Fig. $1(\mathrm{G}-\mathrm{H})$ ). Massai grass grown with $1.9 \mathrm{mmol} \mathrm{L}^{-1} \mathrm{~S}$ did not present any type of chlorosis in the first newly expanded leaf of the plants exposed to Cd (Fig. 1(I)).

\subsection{Variables/Plant Responses Selected Using Random Forests}

The random forests analysis indicated that the most important variable related to $\mathrm{Cd}$ accumulation inside the nutritional parameters was the $\mathrm{Cd}$ translocation factor (TF) in the leaf blades and the stems and sheaths of Massai grass, while in the roots, it was Ca concentration (Table 3). In the leaf blades and the stems and sheaths, Cd concentration was the second most important variable associated to $\mathrm{Cd}$ accumulation, while in the roots, $\mathrm{Cd}$ concentration was the third most important variable. Among the metabolic parameters, the most important variables related to $\mathrm{Cd}$ accumulation of Massai grass were glycine, spermidine, and raffinose concentrations in the leaf blades, stems and sheaths, and roots, respectively (Table 3 ). In the leaf blades of Massai grass, sugars such as fucose, glucose, and galactinol were associated to $\mathrm{Cd}$ accumulation. Galactinol was also associated to $\mathrm{Cd}$ accumulation in the stems and sheaths and roots. In the roots, amino acids containing $\mathrm{S}$ (cysteine and methionine), were among the five most important variables associated to $\mathrm{Cd}$ accumulation in Massai grass. The most important antioxidant variables related to $\mathrm{Cd}$ accumulation in the

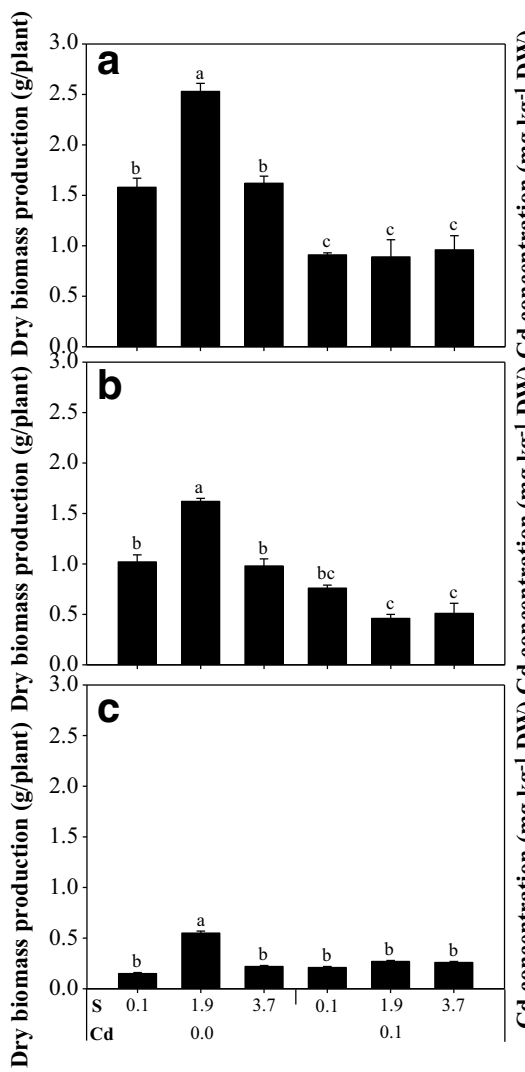

Fig. 1 Dry biomass production (A, B, and C) and Cd concentration (D, E, and F) in the leaf blades (top row), stems and sheaths (middle row), and roots (bottom row) and symptoms of Cd toxicity in the shoots $(\mathrm{G}$ and $\mathrm{H})$ and in the first newly expanded leaf (I) of Massai grass supplied with $\mathrm{S}\left(0.1,1.9\right.$, and $\left.3.7 \mathrm{mmol} \mathrm{L}^{-1}\right)$ and

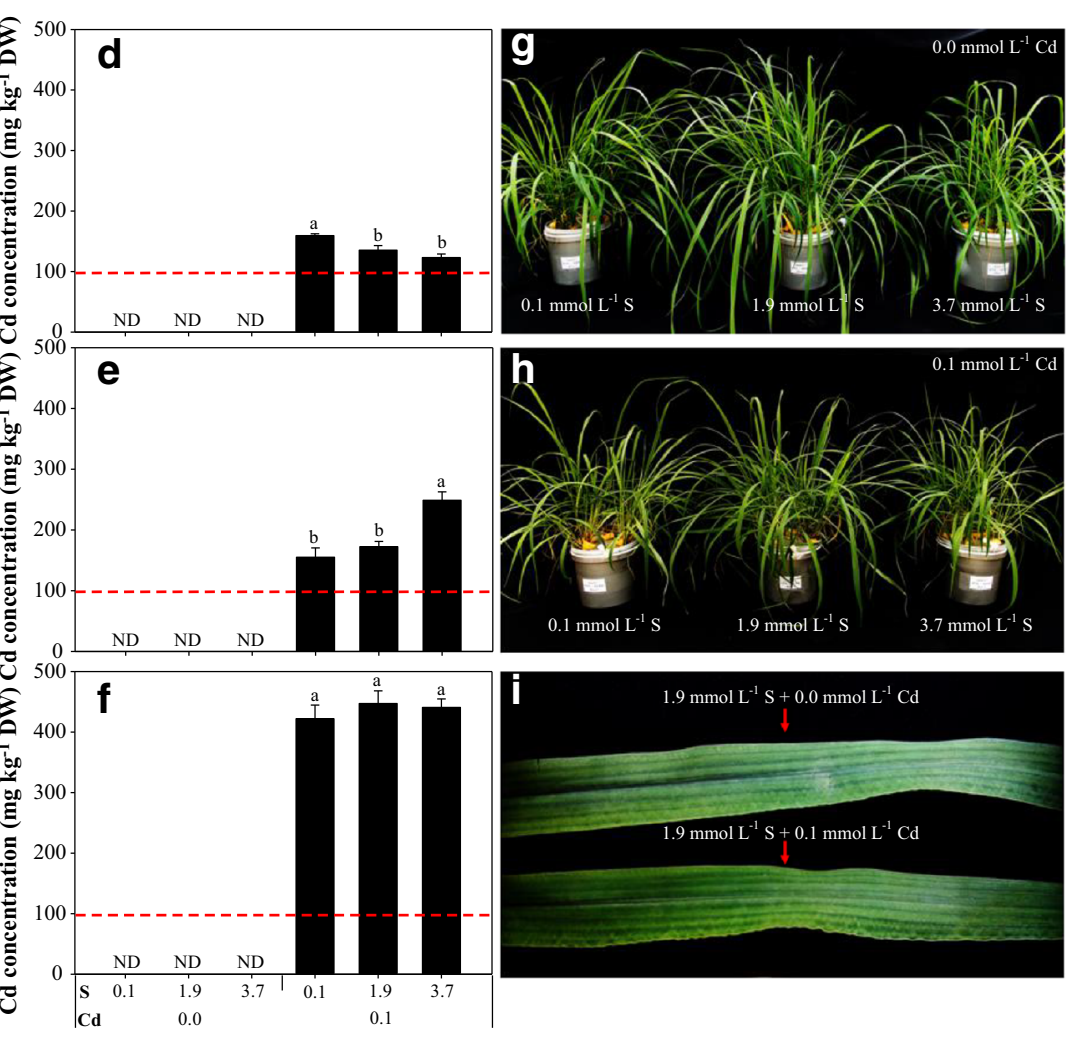

exposed to $\mathrm{Cd}\left(0.0\right.$ and $\left.0.1 \mathrm{mmol} \mathrm{L}^{-1}\right)$. Different letters on the bars indicate significant statistical difference by the Tukey test $(p \leq$ $0.05)$. ND non-detected. Pictures (G, H, and I) were taken in the last day of this study, after 9 days of exposure to $\mathrm{Cd}$ 
Table 3 Selected variables or plant responses for each variable category from the study of Massai grass supplied with $\mathrm{S}(0.1,1.9$, and $\left.3.7 \mathrm{mmol} \mathrm{L}^{-1}\right)$ and exposed to $\mathrm{Cd}\left(0.0\right.$ and $\left.0.1 \mathrm{mmol} \mathrm{L}^{-1}\right)$ using random forests

\begin{tabular}{|c|c|c|c|c|c|}
\hline Leaf blades & $\begin{array}{l}\text { \%Inc } \\
\mathrm{MSE}^{1}\end{array}$ & Stems and sheaths & $\begin{array}{l}\text { \%Inc } \\
\text { MSE }\end{array}$ & Roots & $\begin{array}{l}\text { \%Inc } \\
\text { MSE }\end{array}$ \\
\hline \multicolumn{6}{|l|}{ Nutritional variables } \\
\hline $\mathrm{Cd}$ translocation factor & & Cd translocation factor & & Ca concentration & 五 \\
\hline Cd concentration & & $\mathrm{Cd}$ concentration & & Fe accumulation & \\
\hline $\mathrm{Cu}$ accumulation & & K concentration & & Cd concentration & \\
\hline $\mathrm{K}$ concentration & & $\mathrm{P}$ accumulation & & $\mathrm{Fe}$ concentration & \\
\hline Fe accumulation & & $\mathrm{K}$ accumulation & & $\mathrm{Cu}$ concentration & \\
\hline \multicolumn{6}{|l|}{ Metabolic variables } \\
\hline Glycine concentration & & Spermidine concentration & & Raffinose concentration & \\
\hline Benzoate concentration & & Glycerate concentration & & Cysteine concentration & \\
\hline Fucose concentration & & Leucine concentration & & Galactinol concentration & \\
\hline Glucose concentration & & $\begin{array}{l}\text { Oxaloacetate } \\
\text { concentration }\end{array}$ & & Cellobiose concentration & \\
\hline Galactinol concentration & & Galactinol concentration & & $\begin{array}{c}\text { Methionine } \\
\text { concentration }\end{array}$ & 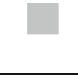 \\
\hline \multicolumn{6}{|l|}{ Antioxidant variables } \\
\hline GSSG concentration & 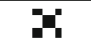 & MDA concentration & Zn' & APX activity & 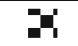 \\
\hline GSH/GSSG ratio & & GPOX activity & & CAT activity & \\
\hline GSH concentration & & GR activity & & GR activity & \\
\hline DHA concentration & & GSSG concentration & & GSH/GSSG ratio & 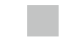 \\
\hline GST activity & & CAT activity & & GST activity & \\
\hline \multicolumn{6}{|c|}{ Productive, photosynthetic and morphological variables } \\
\hline Dry biomass production & ה. & Dry biomass production & III & Tolerande index to $\mathrm{Cd}$ & III \\
\hline Stomatal conductiance & & Growth inhibition & & Growth inhibition & \\
\hline Water use efficiency & & Number of tillers & $\square$ & Root surface & \\
\hline Specific leaf area & & - & - & Dry biomass production & \\
\hline Growth inhibition & & - & - & Root length & \\
\hline \multicolumn{6}{|l|}{ Thiolic variables } \\
\hline $\mathrm{PC}_{6}$ concentration & & Total PCs concentration & & $\begin{array}{l}\text { Total NPTs } \\
\text { concentration }\end{array}$ & \\
\hline $\begin{array}{l}\text { Total NPTs } \\
\text { concentration }\end{array}$ & & cys $\mathrm{PC}_{2}$ concentration & 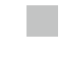 & $\mathrm{PC}_{2}$ concentration & \\
\hline h-GSH concentration & & h- $\mathrm{PC}_{3}$ concentration & 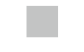 & $\mathrm{PC}_{3}$ concentration & 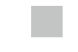 \\
\hline Total PCs concentration & & $\mathrm{PC}_{5}$ concentration & 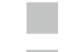 & $\mathrm{PC}_{4}$ concentration & 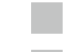 \\
\hline h- $\mathrm{PC}_{4}$ concentration & 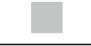 & h- $\mathrm{PC}_{4}$ concentration & 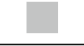 & h- $\mathrm{PC}_{2}$ concentration & 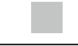 \\
\hline
\end{tabular}

${ }^{1}$ Percentage of increase in the mean square-error (\%Inc MSE): 0 - $10(\mathbf{\square}), 11$ - 30 ( ), 31 - 50 (1) and 51 - 70 (III). GSSG: oxidized glutathione; GSH: reduced glutathione; DHA: dehydroascorbate; GST: glutathione S-transferase; PCs: phytochelatins; NPTs: non-protein thiols; h-GSH: homoglutathione; h-PC: homophytochelatin; MDA: malondialdehyde; GPOX: guaiacol peroxidase; GR: glutathione reductase; CAT: catalase; cys PC: cysteine phytochelatin; APX: ascorbate peroxidase

leaf blades, stems and sheaths, and roots were oxidized glutathione (GSSG) and malondialdehyde (MDA) concentrations and ascorbate peroxidase (APX) activity (Table 3), respectively. Glutathione metabolism is strongly associated to $\mathrm{Cd}$ accumulation in the leaf blades of Massai grass, since GSH/GSSG ratio, GSH concentration, and glutathione-S-transferase (GST) activity were among the five most important antioxidant 
variables related to $\mathrm{Cd}$ accumulation in this tissue. On the other hand, enzymes involved on hydrogen peroxide $\left(\mathrm{H}_{2} \mathrm{O}_{2}\right)$ scavenging (catalase (CAT), APX, and guaiacol peroxidase (GPOX)) and GSH restorations (glutathione reductase (GR)) were apparently more important in the stems and sheaths and roots. The dry biomass production was the most important variable related to $\mathrm{Cd}$ accumulation in the leaf blades and the stems and sheaths of Massai grass when considered only the productive, photosynthetic, and morphological parameters, while the tolerance index (TI) to $\mathrm{Cd}$ was the most important variable in the roots (Table 3 ). In the leaf blades, the stomatal conductance $\left(g_{\mathrm{s}}\right)$ and the water use efficiency (WUE), which are variables associated to water relations, were the second and third most important variables associated to $\mathrm{Cd}$ accumulation considering only the productive, photosynthetic, and morphological parameters. The growth inhibition was the second most important productive variable associated to $\mathrm{Cd}$ accumulation in the stems and sheaths and roots of Massai grass. Root surface and root length were among the five most important variables related to $\mathrm{Cd}$ accumulation in the roots of Massai grass. Among the thiolic parameters, $\mathrm{PC}_{6}$ concentration, total $\mathrm{PCs}$, and total nonprotein thiol (NPT) concentrations were the most important variables related to $\mathrm{Cd}$ accumulation in the leaf blades, stems and sheaths, and roots of Massai grass, respectively (Table 3). Total NPTs, homoglutathione (hGSH), total PCs, and homophytochelatin 4 (h- $\left.\mathrm{PC}_{4}\right)$ concentrations were among the five most important variables related to $\mathrm{Cd}$ accumulation in the leaf blades of Massai grass. Phytochelatins synthesis was strongly related to $\mathrm{Cd}$ accumulation in the stems and sheaths (cys $\mathrm{PC}_{2}, \mathrm{~h}-\mathrm{PC}_{3}, \mathrm{PC}_{5}$, and h- $\left.\mathrm{PC}_{4}\right)$ and roots $\left(\mathrm{PC}_{2}, \mathrm{PC}_{3}, \mathrm{PC}_{4}\right.$, and $\mathrm{h}-\mathrm{PC}_{2}$ ) of this forage grass as well.

When we applied the random forests analysis to our results to analyze the most important variables related to $\mathrm{Cd}$ accumulation, disregarding the categories used in Table 3, we observed that Cd concentration was the most important variable for the leaf blades and the stems and sheaths, while the TI was the most important variable for the roots of Massai grass (Table 4). In the leaf blades, Cd TF, GSSG concentration, and GSH/GSSG ratio were as important as $\mathrm{Cd}$ concentration to explain $\mathrm{Cd}$ accumulation in this tissue by this forage grass. The nutritional variables $(\mathrm{Cu}, \mathrm{K}, \mathrm{Fe}, \mathrm{Mg}$, and $\mathrm{P}$ accumulations) and dry biomass production were important variables associated to $\mathrm{Cd}$ accumulation in the leaf blades of Massai grass. In the stems and sheaths, metabolic (glycerate, leucine, and spermidine concentrations) and nutritional (K concentration and $\mathrm{N}, \mathrm{P}$, and $\mathrm{K}$ accumulations) variables were among the 10 most important variables related to $\mathrm{Cd}$ accumulation by Massai grass. The activities of enzymes involved on $\mathrm{H}_{2} \mathrm{O}_{2}$ scavenging (CAT and APX) and Ca concentration in the roots of the forage grass were as associated to $\mathrm{Cd}$ accumulation as TI. Compounds synthesized to mitigate the oxidative stress Cd-induced and act as Cd chelator (total NPTs, cysteine, $\mathrm{PC}_{4}$ and $\mathrm{PC}_{3}$ concentrations) were also important to explain $\mathrm{Cd}$ accumulation in the roots of Massai grass (Table 4).

3.3 The Pearson Correlation Between Cd Accumulation and the Variables/Plant Responses Selected by Random Forests

To analyze the correlation between $\mathrm{Cd}$ accumulation and the variables related to $\mathrm{Cd}$ accumulation in the different tissues of Massai grass, we performed a Pearson correlation study (Table 5). The highest correlation coefficients $(r \geq 0.95)$ were between the Cd concentration and $\mathrm{Cd}$ accumulation $(r=0.95)$ and the TF and $\mathrm{Cd}$ accumulation $(r=0.95)$ in the leaf blades and between the total NPT concentration and $\mathrm{Cd}$ accumulation $(r=$ 0.97) and the $\mathrm{Cd}$ concentration and $\mathrm{Cd}$ accumulation $(r=0.98)$ in the roots of Massai grass (Table 5). There was a negative correlation between $\mathrm{Cd}$ accumulation and dry biomass production and $\mathrm{Cu}, \mathrm{K}, \mathrm{Fe}, \mathrm{Mg}$, and $\mathrm{P}$ accumulations in the leaf blades; between $\mathrm{Cd}$ accumulation and dry biomass production and $\mathrm{K}$ concentration and $\mathrm{N}, \mathrm{P}$, and $\mathrm{K}$ accumulations in the stems and sheaths; and between $\mathrm{Cd}$ accumulation and TI and Ca concentration and the activities of CAT and APX in the roots of Massai grass (Table 5).

\section{Discussion}

As mentioned in Section 1, we used the data from previously published studies (Rabêlo et al. 2018b, c, d) to conduct this study, where our aim was to identify the main plant responses related to $\mathrm{Cd}$ accumulation in the Massai grass. In this context, we briefly discussed the effect of S on plant responses to $\mathrm{Cd}$. Regardless of S supply, the dry biomass production of Massai grass exposed to $\mathrm{Cd}$ decreased by around $50 \%$ in relation to the control treatment (0.0 mmol L ${ }^{-1} \mathrm{Cd}$ and $1.9 \mathrm{mmol} \mathrm{L}^{-1} \mathrm{~S}$ ) (Fig. 1(A-C)), which can be attributed to high $\mathrm{Cd}$ concentrations (> 
Table 4 Global variables/plant responses selection from the study of Massai grass supplied with $\mathrm{S}\left(0.1,1.9\right.$, and $\left.3.7 \mathrm{mmol} \mathrm{L}^{-1}\right)$ and exposed to $\mathrm{Cd}\left(0.0\right.$ and $\left.0.1 \mathrm{mmol} \mathrm{L}^{-1}\right)$ using random forests

\begin{tabular}{|c|c|c|c|c|c|}
\hline Leaf blades & $\%$ IncMSE $^{1}$ & Stems and sheaths & $\%$ IncMSE & Roots & \%IncMSE \\
\hline Cd concentration & & Cd concentration & & Tolerance index to $\mathrm{Cd}$ & \\
\hline $\mathrm{Cd}$ translocation factor & & $\mathrm{Cd}$ translocation factor & & CAT activity & \\
\hline GSSG concentration & & Glycerate concentration & & APX activity & \\
\hline GSH/GSSG ratio & & Leucine concentration & & $\mathrm{Ca}$ concentration & \\
\hline $\mathrm{Cu}$ accumulation & & $\mathrm{K}$ concentration & & Total NPTs concentration & \\
\hline $\mathrm{K}$ accumulation & & Spermidine concentration & & Fe accumulation & \\
\hline Dry biomass production & & Dry biomass production & & $\mathrm{Cd}$ concentration & \\
\hline Fe accumulation & & $\mathrm{N}$ accumulation & & Cysteine concentration & \\
\hline Mg accumulation & & $\mathrm{P}$ accumulation & & $\mathrm{PC}_{4}$ concentration & \\
\hline $\mathrm{P}$ accumulation & & $\mathrm{K}$ accumulation & & $\mathrm{PC}_{3}$ concentration & \\
\hline
\end{tabular}

${ }^{1}$ Percentage of increase in the mean square-error (\%Inc MSE): 0 - $10(\square)$ and $11-30(\square)$. GSSG: oxidized glutathione; GSH: reduced glutathione; CAT: catalase; APX: ascorbate peroxidase; NPTs: non-protein thiols; PCs: phytochelatins

$100 \mathrm{mg} \mathrm{kg}^{-1} \mathrm{DW}$ ) observed in the tissues of Massai grass exposed to $0.1 \mathrm{mmol} \mathrm{L}^{-1} \mathrm{Cd}$ (Fig. 1(D-F)). Gallego et al. (2012) reported that high Cd concentrations may cause lowest root development, disorders in nutrient assimilation, lipid peroxidation, and inactivation of enzymes involved in $\mathrm{CO}_{2}$ fixation, which results in lowest dry biomass. Rabêlo et al. (2017a) reported that the dry biomass production of Panicum maximum cv. Tanzânia (Tanzania guinea grass) exposed to $\mathrm{Cd}$ decreased also compared with control. The authors attributed this fact to reduced tillering and emission of leaves by the plants due to lipid peroxidation $\mathrm{Cd}$ induced in the shoots. In this scenario of lowest dry biomass production, it is necessary more time to clean up $\mathrm{Cd}$ contaminated soils, since Cd phytoextraction potential is strongly associated with the dry biomass production (Vangronsveld et al. 2009).

Cadmium also changes the structure of chloroplasts and degrades photosynthetic pigments, which may

Table 5 The Pearson correlation between $\mathrm{Cd}$ accumulation and the selected variables/plant responses using random forests from the study of Massai grass supplied with $\mathrm{S}\left(0.1,1.9\right.$, and $\left.3.7 \mathrm{mmol} \mathrm{L}^{-1}\right)$ and exposed to $\mathrm{Cd}\left(0.0\right.$ and $\left.0.1 \mathrm{mmol} \mathrm{L}^{-1}\right)(n=24)$

\begin{tabular}{|c|c|c|c|c|c|}
\hline \multicolumn{2}{|l|}{ Leaf blades } & \multicolumn{2}{|l|}{ Stems and sheaths } & \multicolumn{2}{|l|}{ Roots } \\
\hline Variables & Cd accumulation & Variables & Cd accumulation & Variables & Cd accumulation \\
\hline Cd concentration & $0.95 * *$ & Cd concentration & $0.92 * *$ & Tolerance index to $\mathrm{Cd}$ & $-0.92 * *$ \\
\hline $\mathrm{Cd}$ translocation factor & $0.95 * *$ & $\mathrm{Cd}$ translocation factor & $0.94 * *$ & CAT activity & $-0.81 * *$ \\
\hline GSSG concentration & $0.69 *$ & Glycerate concentration & $0.80 * *$ & APX activity & $-0.86 * *$ \\
\hline GSH/GSSG ratio & $0.10 \mathrm{~ns}$ & Leucine concentration & $0.71 * *$ & Ca concentration & $-0.83 * *$ \\
\hline $\mathrm{Cu}$ accumulation & $-0.81 * *$ & $\mathrm{~K}$ concentration & $-0.76^{* *}$ & Total NPT concentration & $0.97 * *$ \\
\hline $\mathrm{K}$ accumulation & $-0.71 * *$ & Spermidine concentration & $0.81 * *$ & Fe accumulation & $0.93 * *$ \\
\hline Dry biomass production & $-0.68^{*}$ & Dry biomass production & $-0.60 *$ & Cd concentration & $0.98 * *$ \\
\hline Fe accumulation & $-0.65 *$ & $\mathrm{~N}$ accumulation & $-0.66^{*}$ & Cysteine concentration & $0.89 * *$ \\
\hline Mg accumulation & $-0.63 *$ & $\mathrm{P}$ accumulation & $-0.64 *$ & $\mathrm{PC}_{4}$ concentration & $0.92 * *$ \\
\hline $\mathrm{P}$ accumulation & $-0.74 * *$ & $\mathrm{~K}$ accumulation & $-0.69 *$ & $\mathrm{PC}_{3}$ concentration & $0.92 * *$ \\
\hline
\end{tabular}

$* * p \leq 0.0001$

$* p \leq 0.05$

ns not significant, GSSG oxidized glutathione, GSH reduced glutathione, CAT catalase, APX ascorbate peroxidase, NPTs non-protein thiols, $P C$ phytochelatin 
result in chlorosis and accelerated leaf senescence, leading to plant death (Bashir et al. 2015a). However, after 9 days of exposure to $\mathrm{Cd}$, Massai grass did not show any symptoms of chlorosis and leaf necrosis, mainly when the plants were supplied with $1.9 \mathrm{mmol} \mathrm{L}^{-1} \mathrm{~S}$ (Fig. $1(\mathrm{G}-$ I)). This result may be related to the high synthesis of GSH and PCs observed in the roots and stems and sheaths of Massai grass exposed to $\mathrm{Cd}$, and supplied with $1.9 \mathrm{mmol} \mathrm{L}^{-1} \mathrm{~S}$, and to the high synthesis of antioxidants such as glucose and sucrose observed in the leaf blades of these plants (Rabêlo et al. 2018c). As GSH and PCs act on chelation of free $\mathrm{Cd}^{2+}$ ions in the cytosol (Cobbett and Goldsbrough 2002), there is less $\mathrm{Cd}$ translocation from roots to stems and from stems to leaf blades (Mendoza-Cózatl et al. 2005). Glucose and sucrose act on reactive oxygen species (ROS) scavenging in the chloroplasts and in the stabilization of the photosynthetic process under stress conditions (Keunen et al. 2013). Reduced glutathione and PCs are compounds rich in cysteine, which is the initial product of $\mathrm{S}$ assimilation and it is supposed to be the limiting factor for GSH and PC synthesis (Mendoza-Cózatl et al. 2005). In this sense, the proper $S$ supply is important for GSH and PC synthesis, since S starvation or excess S supply change the S metabolism. Dong et al. (2017) reported that Arabidopsis thaliana grown with limited $\mathrm{S}$ supply presented lower glucose synthesis in their leaves, since $\mathrm{S}$ deficiency decreased the target of rapamycin (TOR) activity, and we know that glucose and its metabolization in the tricarboxylic acid (TCA) cycle is a well-established trigger of TOR in plants. Thus, plants grown with proper S supply presents more glucose as well as sucrose synthesis, since sucrose is a polymer of fructose and glucose, which can mitigate the Cd-induced stress in plants. Bashir et al. (2015b) reported higher GSH and PC synthesis and lower chlorophyll degradation in Brassica juncea exposed to $\mathrm{Cd}$ when there was proper S supply. The absence of visual symptoms of Cd toxicity in the leaves of Massai grass (Fig. 1(I)) suggests us that this plant can be more tolerant to $\mathrm{Cd}$ than others Panicum maximum genotypes (Rabêlo et al. 2017a, b).

As the efficiency of Cd phytoextraction depends on two main variables: $\mathrm{Cd}$ concentration in the shoots and biomass production (Vangronsveld et al. 2009), it is clear that Massai grass presents great potential for $\mathrm{Cd}$ phytoextraction when compared with $\mathrm{Cd}$ hyperaccumulator plants (Rabêlo and Borgo 2016), even presenting lowest dry biomass production when exposed to $\mathrm{Cd}$ (Fig. 1(A-C)). In this sense, it is important to identify the plant responses related to $\mathrm{Cd}$ accumulation in the Massai grass and to understand how these responses are associated to $\mathrm{Cd}$ tolerance, since the forage grasses present different physiological systems from the $\mathrm{Cd}$ hyperaccumulators plants identified until this moment (Reeves et al. 2017; Rabêlo et al. 2018a). In Tables 3 and 4 , we can observe that responses related to $\mathrm{Cd}$ accumulation in the roots, stems and sheaths, and leaf blades of Massai grass are a little bit different. While in the shoots, the variables that most explained $\mathrm{Cd}$ accumulation in the Massai grass were $\mathrm{Cd}$ concentration and $\mathrm{TF}$, in the roots, were TI and CAT activity (Table 4). Cadmium accumulation in the shoots of Massai grass increased when $\mathrm{Cd}$ concentration and TF also increased (Table 5), which is expected since there is an effect of concentration of $\mathrm{Cd}$ in the shoots (Ekvall and Greger 2003), as occurred in Avena fatua and in Lolium temulentum (Marzban et al. 2017). Non-hyperaccumulator plants (e.g., Massai grass) exposed to $\mathrm{Cd}$ normally try to bind $\mathrm{Cd}$ in the root cell walls or enhance the synthesis of $\mathrm{Cd}$ chelators to avoid $\mathrm{Cd}$ translocation from roots to shoots (Clemens 2006). However, when these processes are not enough to store $\mathrm{Cd}$ in the roots, $\mathrm{Cd}$ translocation to shoots increases, as observed in several forage grasses (Rabêlo et al. 2017b, 2018a). In this sense, Cd translocation from roots to shoots is strongly regulated by root responses to $\mathrm{Cd}$ in Massai grass, as observed in other plants (Clemens et al. 2013).

There was a negative correlation between TI and CAT activity with $\mathrm{Cd}$ accumulation in the roots of Massai grass (Table 5). This occur because the disintegration of cortical root cells and the loss of cellular turgor tend to increase when $\mathrm{Cd}$ concentrations and $\mathrm{Cd}$ accumulations are higher, which decreases the root growth (Lux et al. 2011) and, consequently, the TI of the plants, since the TI is calculated from root length (Wilkins 1978). Marzban et al. (2017) described also lower root length and TI in Avena fatua, Lathyrus sativus, and Lolium temulentum exposed to $\mathrm{Cd}$. The exposure to $\mathrm{Cd}$ also results in highest ROS generation (Gallego et al. 2012), as the superoxide radical $\left(\mathrm{O}_{2}{ }^{-}\right)$, which inactivates CAT rapidly and decreases its activity (Kono and Fridovich 1982). Rabêlo et al. (2017b) reported that CAT activity in the roots of Tanzania guinea grass exposed to $2 \mathrm{mmol} \mathrm{L}{ }^{-1} \mathrm{Cd}$ was almost 50\% lower compared with control, and there was no effect of S supply on CAT activity. It is important to highlight that in our study, there was also no significant effect of $\mathrm{S}$ on 
CAT activity in the roots of Massai grass (Rabêlo et al. 2018d). Catalase inactivation can result in highest lipid peroxidation, negatively affecting cell expansion and in turn the root growth, which can decrease soil exploitation and $\mathrm{Cd}$ phytoextraction potential. In this sense, the plants have to develop other mechanisms to cope with Cd-induced stress, as seems to be the case of the Massai grass.

Besides the Cd concentration and TF, the concentration of oxidized glutathione (GSSG), GSH/GSSG ratio, the accumulations of $\mathrm{Cu}, \mathrm{K}, \mathrm{Fe}, \mathrm{Mg}$, and $\mathrm{P}$, and the dry biomass production were the other variables that most explained the $\mathrm{Cd}$ accumulation in the shoots of Massai grass (Table 4). There was a positive correlation between GSSG concentration and Cd accumulation in the shoots of Massai grass (Table 5), which initially suggests that plants presenting low GSSG concentrations can accumulate more $\mathrm{Cd}$, but it normally does not occur in practice. High $\mathrm{Cd}$ concentrations can cause depletion in GSH pools and inactivation of GR, which restore GSSG in GSH, which results in higher GSSG concentration (Jozefczak et al. 2015). Bashir et al. (2015b) found higher GSSG concentration in the shoots of Brassica juncea exposed to $\mathrm{Cd}$ in relation to control. High GSSG concentrations seem to be more related to an inefficient antioxidant system than some mechanism which allows $\mathrm{Cd}$ accumulation. Besides inducing ROS generation, $\mathrm{Cd}$ can inhibit the nutrient uptake by competing for the same sites of uptake in the roots (Clemens 2006; Lux et al. 2011), among other factors. This fact associated to the lowest dry biomass production results in negative correlations between $\mathrm{Cd}$ concentration and nutrient accumulation (Table 5). Jozefczak et al. (2015) reported also lower $\mathrm{K}$ accumulation in the shoots of Arabidopsis thaliana exposed to $\mathrm{Cd}$. Lower $\mathrm{K}, \mathrm{Ca}, \mathrm{Mg}, \mathrm{Cu}, \mathrm{Fe}$, and $\mathrm{Zn}$ accumulations were also reported by Wang et al. (2013) in the shoots of Lolium perenne exposed to Cd. Rabêlo and Borgo (2016) reported in a study review that $\mathrm{Cu}, \mathrm{Fe}, \mathrm{Mn}$, and $\mathrm{Zn}$ accumulations in the shoots of Brachiaria decumbens and Panicum mosambicence exposed to $\mathrm{Cd}$ decreased when compared with the control. The lower nutrient accumulations in the shoots of the plants exposed to $\mathrm{Cd}$ can become a serious problem, mainly in the case of the micronutrients, which are used as co-factor by enzymes involved on ROS scavenging (Rabêlo and Borgo 2016). However, Rabêlo et al. (2018d) described that the antioxidant enzymes are not so important for Massai grass to cope with Cd-induced stress, as observed in other plants (Bashir et al. 2015b; Jozefczak et al. 2015).

The concentrations of glycerate, leucine, spermidine, and $\mathrm{K}$, accumulations of $\mathrm{N}, \mathrm{P}$, and $\mathrm{K}$, and dry biomass production were the responses (besides $\mathrm{Cd}$ concentration and $\mathrm{TF}$ ) that most explained $\mathrm{Cd}$ accumulation in the stems and sheaths of Massai grass (Table 4). There was a positive correlation only between $\mathrm{Cd}$ accumulation and the concentrations of glycerate, leucine, and spermidine (Table 5). Although the glycerate concentration is related to $\mathrm{Cd}$ accumulation in the stems and sheaths of Massai grass, there are no reports in the literature on its function in this tissue of plants exposed to $\mathrm{Cd}$. On the other hand, spermidine is an important antioxidant that regulates the expression of genes expressed under stress conditions (Kasukabe et al. 2004), whereas leucine can act in the promotion of the protein synthesis induced in stress conditions, besides acting as signaling molecule for gene expression (Joshi et al. 2010). To the best of our knowledge, there are no studies with forage grasses assessing $\mathrm{Cd}$ exposure on secondary metabolites of the TCA cycle (e.g., glycerate and spermidine), which is an important gap to be explored in further studies. Rabêlo et al. (2017b) observed that leucine concentration did not increase in the shoots of Tanzania guinea grass due to $\mathrm{Cd}$ exposure, but there was increase in this amino acid concentration due to proper S supply. In our study, there was no significant $\mathrm{S}$ effect on leucine and spermidine synthesis (Rabêlo et al. 2018c), but even so, the secondary metabolites of the TCA cycle were very important for Massai grass to cope with $\mathrm{Cd}$-induced stress (Rabêlo et al. 2018c, d).

Cadmium accumulation in the stems and sheaths of Massai grass correlated negatively with the accumulations of some nutrients (Table 5), as observed in the leaf blades. However, there were no symptoms of $\mathrm{N}, \mathrm{P}, \mathrm{K}, \mathrm{Mg}, \mathrm{Cu}$, and/or Fe deficiency in the shoots of Massai grass exposed to Cd (Fig. 1(G-I)), indicating that Massai grass survives in a wide nutritional range, which is essential for plants used for Cd phytoextraction. Rabêlo et al. (2017b) reported that the variation caused by $\mathrm{Cd}$ on $\mathrm{N}, \mathrm{P}, \mathrm{K}, \mathrm{Ca}, \mathrm{Mg}$, $\mathrm{Fe}, \mathrm{Mn}$, and $\mathrm{Zn}$ concentrations may have contributed to inhibit plant regrowth after the first shoot 
harvest. The low nutrient accumulation like $\mathrm{N}$ could limit the synthesis of $\mathrm{Cd}$ chelators, such as PCs (Sarwar et al. 2010). However, this did not occur with Massai grass (Rabêlo et al. 2018c), which is important since the PC pathway is between the most important mechanisms of $\mathrm{Cd}$ detoxification in plants (Clemens 2006). This is clear when we observed that concentrations of cysteine, $\mathrm{PC}_{3}, \mathrm{PC}_{4}$, and NPTs are among the 10 responses that most explained $\mathrm{Cd}$ accumulation in the roots of Massai grass (Table 4) and that there was positive correlation among these responses and $\mathrm{Cd}$ accumulation (Table 5). It is important to note that cysteine is a structural component of GSH, which in turn is a component of PCs (Cobbett and Goldsbrough 2002), and that $\mathrm{PC}_{3}$ and $\mathrm{PC}_{4}$ are among the major NPTs induced by $\mathrm{Cd}$ in plants (Vázquez et al. 2006). Santos et al. (2011) noted that the PC synthesis in the roots of Brachiaria decumbens was also critical to the survival of this forage to Cd. Phytochelatins form complexes with $\mathrm{Cd}$ in the cytosol and subsequently transported it into the vacuole, decreasing its toxicity (Cobbett and Goldsbrough 2002; Clemens 2006). In this sense, it is important to supply $\mathrm{S}$ for the plants since the thiol compounds (e.g., cysteine, $\mathrm{GSH}$, and PCs) are compounds rich in S, and a lower $\mathrm{S}$ concentration can limit their synthesis (Mendoza-Cózatl et al. 2005). In general, we observed in this study that the proper S supply (1.9 $\mathrm{mmol} \mathrm{L}^{-1}$ ) allowed higher cysteine, GSH, and
PC syntheses in the stems and sheaths and the roots of Massai grass compared with the inadequate $\mathrm{S}$ supply (0.1 $\left.\mathrm{mmol} \mathrm{L}^{-1}\right)$ (Rabêlo et al. 2018c). The proper S supply also increased the NPT and PC syntheses in Brassica juncea (Bashir et al. 2015b) and GSH synthesis in Tanzania guinea grass exposed to Cd (Rabêlo et al. 2017a). Higher thiol compound synthesis can decrease the damages caused by $\mathrm{Cd}$ allowing higher $\mathrm{Cd}$ uptake, which in turn may increase the $\mathrm{Cd}$ phytoextraction potential of the plant.

The concentrations of $\mathrm{Ca}$ and $\mathrm{Cd}, \mathrm{Fe}$ accumulation, and APX activity were the other plant responses that most explained $\mathrm{Cd}$ accumulation in the roots of Massai grass, besides the TI, CAT activity, and concentrations of cysteine, $\mathrm{PC}_{3}, \mathrm{PC}_{4}$, and NPTs (Table 4). Cadmium competes with $\mathrm{Ca}$ by the same root uptake sites (Lux et al. 2011) and induces the formation of Fe plaques in the roots of the plants (Du et al. 2013), which results in a negative correlation between $\mathrm{Ca}$ concentration and $\mathrm{Cd}$ accumulation and in a positive correlation among $\mathrm{Cd}$ and $\mathrm{Fe}$ accumulations (Table 5). Firstly, $\mathrm{Cd}$ induces changes in the $\mathrm{Fe}^{2+} / \mathrm{Mn}^{2+}$ availability, redox potential, and the concentration of radial oxygen loss in the root, and then, the oxygen released from the aerenchyma oxidizes $\mathrm{Fe}^{2+}$ to $\mathrm{Fe}^{3+}$, and $\mathrm{Fe}^{3+}$ oxide precipitates on the root surface, forming the Fe plaques (Du et al. 2013). Christensen and Sand-Jensen (1998) noted that there was a negative correlation between Fe plaque
Fig. 2 Variables/plant responses that most explain $\mathrm{Cd}$ accumulation in Massai grass supplied with $\mathrm{S}(0.1,1.9$, and $\left.3.7 \mathrm{mmol} \mathrm{L}^{-1}\right)$ and exposed to $\mathrm{Cd}$ (0.0 and $0.1 \mathrm{mmol} \mathrm{L}^{-1}$ ) using random forests analysis

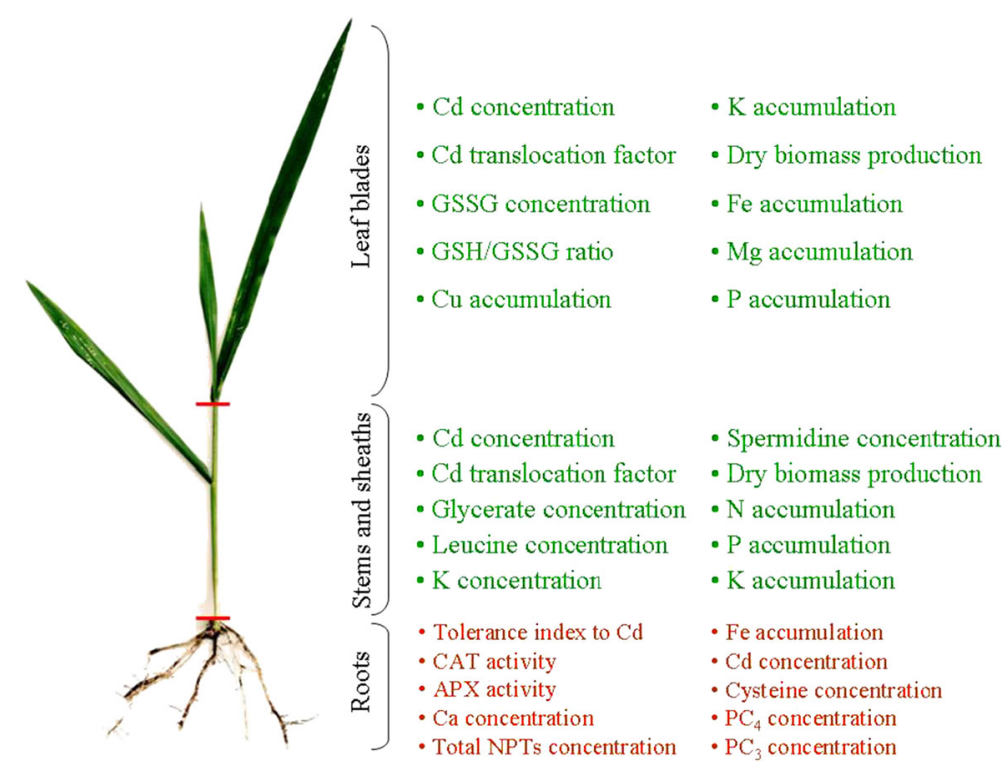


formation in the roots and $\mathrm{Fe}$ concentration in the leaves of Lobelia dortmanna. Iron deficiency can compromise the photosynthetic activity of the plants (Bashir et al. 2015a) and decrease APX activity, since APX is a hemoprotein. Wang et al. (2013) described that $\mathrm{Fe}$ concentration in the roots of Lolium perenne decreased with $\mathrm{Cd}$ exposure compared with the control treatment. In our study, we observed that there was a negative correlation between APX activity and Cd accumulation (Table 5), as occurred with CAT, but there was no Fe deficiency in the roots of Massai grass (Rabêlo et al. 2018b). In this scenario, it is possible that $\mathrm{Cd}$ bound to the APX reaction center and caused inactivation of this enzyme (Schützendübel et al. 2002). Wang et al. (2013) also reported that APX activity in the roots of Lolium perenne decreased with $\mathrm{Cd}$ exposure. It is important to highlight again that antioxidant enzymes apparently are not essential for Massai grass in coping with Cd-induced stress, differently of other mechanisms (e.g., synthesis of thiol compounds and amino acids involved on ROS scavenging and Cd chelation), which allows this genotype to survive to 0.1 mmol L ${ }^{-1} \mathrm{Cd}$ exposure.

\section{Conclusions}

The lowest dry biomass production of the plants exposed to Cd combined with the absence of visual symptoms of Cd toxicity indicates us that Massai grass is not a Cd hyperaccumulator plant, but is a bioindicator plant (van der Ent et al. 2013) that can greatly cope with the $\mathrm{Cd}$-induced stress. Massai grass presented mechanisms of Cd tolerance common to other plants (e.g., PC synthesis in the roots for $\mathrm{Cd}$ chelation), but it is clear that important mechanisms of $\mathrm{Cd}$ tolerance such as high activity of antioxidant enzymes (e.g., CAT and APX) apparently are not essential to $\mathrm{Cd}$ tolerance in this forage grass. Probably, the physiological mechanisms to cope with $\mathrm{Cd}$-induced stress in other forage grasses are very similar to the mechanisms presented by Massai grass. In this sense, the plant responses that most explained $\mathrm{Cd}$ accumulation in Massai grass (summarized in the Fig. 2) can be used to identify forage grasses with high capacity to accumulate $\mathrm{Cd}$ in phytoremediation programs with this group of plants. Apparently, the secondary metabolites of the TCA cycle are important for forage grasses cope with Cd-induced stress, deserving special attention in further studies. In the same way, it is important to conduct further studies with forage grasses for longer periods of time, in soil, to verify how $\mathrm{Cd}$ accumulation is influenced under conditions closer to reality.

Acknowledgments We are grateful to Professor Stephan Clemens at the University of Bayreuth for the suggestions and comments in order to improve the quality of this study.

Funding This research was supported by the Coordination for the Improvement of Higher Education Personnel - CAPES [grant \#1332394] and São Paulo Research Foundation - FAPESP [grants \#2014/16731-7, \#2014/18735-0, \#2014/03310-3, and \#2015/ 21562-2].

\section{Compliance with Ethical Standards}

Conflict of Interest The authors declare that they have no conflict of interest.

\section{References}

Bashir, H., Qureshi, M. I., Ibrahim, M. M., \& Iqbal, M. (2015a). Chloroplast and photosystems: impact of cadmium and iron deficiency. Photosynthetica, 53, 321-335.

Bashir, H., Ibrahim, M. M., Bagheri, R., Ahmad, J., Arif, I. A., Baig, M. A., \& Qureshi, M. I. (2015b). Influence of sulfur and cadmium on antioxidants, phytochelatins and growth in Indian mustard. AoB Plants, 7, plv001.

Breiman, L. (2001). Random forests. Machine Learning, 45, 5-32.

Christensen, K. K., \& Sand-Jensen, K. (1998). Precipitated iron and manganese plaques restrict root uptake of phosphorus in Lobelia dortmanna. Canadian Journal of Botany, 76, 21582163.

Clemens, S. (2006). Toxic metal accumulation, responses to exposure and mechanisms of tolerance in plants. Biochimie, 88 , 1707-1719.

Clemens, S., Aarts, M. G. M., Thomine, S., \& Verbruggen, N. (2013). Plant science: the key to preventing slow cadmium poisoning. Trends in Plant Science, 18, 92-99.

Cobbett, C., \& Goldsbrough, P. (2002). Phytochelatins and metallothioneins: roles in heavy metal detoxification and homeostasis. Annual Review of Plant Biology, 53, 159-182.

Dong, Y., Silbermann, M., Speiser, A., Forieri, I., Linster, E., Poschet, G., Samami, A. A., Watanabe, M., Sticht, C., Teleman, A. A., Deragon, J., Saito, K., Hell, R., \& Wirtz, M. (2017). Sulfur availability regulates plant growth via glucose-TOR signaling. Nature Communications, 8, 1174.

Du, J., Yan, C., \& Li, Z. (2013). Formation of iron plaque on mangrove Kandalar. Obovata (S.L.) root surfaces and its role in cadmium uptake and translocation. Marine Pollution Bulletin, 74, 105-109.

Ekvall, L., \& Greger, M. (2003). Effects of environmental biomass-producing factors on Cd uptake in two Swedish ecotypes of Pinus sylvestris. Environmental Pollution, 121, 401-411. 
Gallego, S. M., Pena, L. B., Barcia, R. A., Azpilicueta, C. E., Iannone, M. F., Rosales, E. P., Zawoznik, M. S., Groppa, M. D., \& Benavides, M. P. (2012). Unravelling cadmium toxicity and tolerance in plants: insight into regulatory mechanisms. Environmental and Experimental Botany, 83, 33-46.

Hoagland, D., \& Arnon, D. I. (1950). The water culture method for growing plants without soil. Berkeley: California Agricultural Experimental Station.

Joshi, V., Joung, J. G., Fei, Z., \& Jander, G. (2010). Interdependence of threonine, methionine and isoleucine metabolism in plants: accumulation and transcriptional regulation under abiotic stress. Amino Acids, 39, 933-947.

Jozefczak, M., Bohler, S., Schat, H., Horemans, N., Guisez, Y., Remans, T., Vangronsveld, J., \& Cuypers, A. (2015). Both the concentration and redox state of glutathione and ascorbate influence the sensitivity of Arabidopsis to cadmium. Annals of Botany, 116, 601-612.

Kasukabe, Y., He, L., Nada, K., Misawa, S., Ihara, I., \& Tachibana, S. (2004). Overexpression of spermidine synthase enhances tolerance to multiple environmental stresses and up-regulates the expression of various stress-regulated genes in transgenic Arabidopsis thaliana. Plant \& Cell Physiology, 45, 712-722.

Keunen, E., Peshev, D., Vangronsveld, J., Van Den Ende, W., \& Cuypers, A. (2013). Plant sugars are crucial players in the oxidative challenge during abiotic stress: extending the traditional concept. Plant, Cell \& Environment, 36, 1242-1255.

Khan, M. A., Khan, S., Khan, A., \& Alam, M. (2017). Soil contamination with cadmium, consequences and remediation using organic amendments. The Science of the Total Environment, 601-602, 1591-1605.

Kono, Y., \& Fridovich, I. (1982). Superoxide radical inhibits catalase. The Journal of Biological Chemistry, 257, 57515754.

Lux, A., Martinka, M., Vaculík, M., \& White, P. J. (2011). Root responses to cadmium in the rhizosphere: a review. Journal of Experimental Botany, 62, 21-37.

Marzban, L., Akhzari, D., Ariapour, A., Mohammadparast, B., \& Pessarakli, M. (2017). Effects of cadmium stress on seedlings of various rangeland plant species (Avena fatua L., Lathyrus sativus L., and Lolium temulentum L.): growth, physiological traits, and cadmium accumulation. Journal of Plant Nutrition, 40, 2127-2137.

Mendoza-Cózatl, D., Loza-Tavera, H., Hernández-Navarro, A., \& Moreno-Sánchez, R. (2005). Sulfur assimilation and glutathione metabolism under cadmium stress in yeast, protists and plants. FEMS Microbiology Reviews, 29, 653-671.

Montgomery, D. C. (1984). Design and analysis of experiments (2nd ed.). New York: Wiley.

Nawrot, T. S., Staessen, J. A., Roels, H. A., Munters, E., Cuypers, A., Richart, T., Ruttens, A., Smeets, K., Clijsters, H., \& Vangronsveld, J. (2010). Cadmium exposure in the population: from health risks to strategies of prevention. Biometals, 23, 769-782.

$\mathrm{R}$ Core Team (2017) [software]. R Foundation for Statistical Computing, Vienna.

Rabêlo, F. H. S., \& Borgo, L. (2016). Changes caused by heavy metals in micronutrient content and antioxidant system of forage grasses used for phytoremediation: an overview. Ciencia Rural, 46, 1368-1375.

Rabêlo, F. H. S., Azevedo, R. A., \& Monteiro, F. A. (2017a). Proper supply of $\mathrm{S}$ increases GSH synthesis in the establishment and reduces tiller mortality during the regrowth of Tanzania guinea grass used for Cd phytoextraction. Journal of Soils and Sediments, 17, 1427-1436.

Rabêlo, F. H. S., Azevedo, R. A., \& Monteiro, F. A. (2017b). The proper supply of S increases amino acid synthesis and antioxidant enzyme activity in Tanzania guinea grass used for $\mathrm{Cd}$ phytoextraction. Water, Air, and Soil Pollution, 228, 394.

Rabêlo, F. H. S., Jordão, L. T., \& Lavres, J. (2017c). A glimpse into the symplastic and apoplastic Cd uptake by Massai grass modulated by sulfur nutrition: Plants well-nourished with $\mathrm{S}$ as a strategy for phytoextraction. Plant Physiology and Biochemistry, 121, 48-57.

Rabêlo, F. H. S., Borgo, L., \& Lavres, J. (2018a). The use of forage grasses for the phytoremediation of heavy metals: plant tolerance mechanisms, classifications, and new prospects. In V. Matichenkov (Ed.), Phytoremediation: methods, management and assessment (pp. 59-103). New York: Nova Science Publishers.

Rabêlo, F. H. S., Lux, A., Rossi, M. L., Martinelli, A. P., Cuypers, A., \& Lavres, J. (2018b). Adequate S supply reduces the damage of high $\mathrm{Cd}$ exposure in roots and increases $\mathrm{N}, \mathrm{S}$ and $\mathrm{Mn}$ uptake by Massai grass grown in hydroponics. Environmental and Experimental Botany, 148, 35-46.

Rabêlo, F. H. S., Fernie, A. R., Navazas, A., Borgo, L., Keunen, E., Silva, B. K. A., Cuypers, A., \& Lavres, J. (2018c). A glimpse into the effect of sulfur supply on metabolite profiling, glutathione and phytochelatins in Panicum maximum cv. Massai exposed to cadmium. Environmental and Experimental Botany, 151, 76-88.

Rabêlo, F. H. S., Silva, B. K. A., Borgo, L., Keunen, E., Rossi, M. L., Borges, K. L. R., Santos, E. F., Reis, A. R., Martinelli, A. P., Azevedo, R. A., Cuypers, A., \& Lavres, J. (2018d). Enzymatic antioxidants - relevant or not to protect the photosynthetic system against cadmium-induced stress in Massai grass supplied with sulfur? Environmental and Experimental Botany, 155, 702-717.

Redovniković, I. R., De Marco, A., Proietti, C., Hanousek, K., Sedak, M., Bilandžić, N., \& Jakovljević, T. (2017). Poplar response to cadmium and lead soil contamination. Ecotoxicology and Environmental Safety, 144, 482-489.

Reeves, R. D., Baker, A. J. M., Jaffré, T., Erskine, P. D., Echevarria, G., \& van der Ent, A. (2017). A global database for plants that hyperaccumulate metal and metalloid trace elements. The New Phytologist, 218, 407-411.

Santos, F. S., Amaral Sobrinho, N. M. B., Mazur, N., Garbisu, C., Barrutia, O., \& Becerril, J. M. (2011). Antioxidant response, phytochelatins formation and photoprotective pigment composition in Brachiaria decumbens Stapf subjected to contamination with cd and Zn. Quim Nova, 34, 16-20.

Sarwar, N., Saifullah, M. S. S., Zia, M. H., Naeem, A., Bibi, S., \& Farid, G. (2010). Role of mineral nutrition in minimizing cadmium accumulation by plants. Journal of the Science of Food and Agriculture, 90, 925-937.

SAS Institute. (2008). Version 9.2. [software]. Cary: SAS Institute. Schützendübel, A., Nikolova, P., Rudolf, C., \& Polle, A. (2002). Cadmium and $\mathrm{H}_{2} \mathrm{O}_{2}$ induced oxidative stress in Populus $\times$ canescens roots. Plant Physiology and Biochemistry, 40, 577-584.

van der Ent, A., Baker, A. J. M., Reeves, R. D., Pollard, A. J., \& Schat, H. (2013). Hyperaccumulators of metal and metalloid 
trace elements: facts and fiction. Plant and Soil, 362, 319334.

Vangronsveld, J., Herzig, R., Weyens, N., Boulet, J., Adriaensen, K., Ruttens, A., Thewys, T., Vassilev, A., Meers, E., Nehnevajova, E., van der Lelie, D., \& Mench, M. (2009). Phytoremediation of contaminated soils and groundwater: lessons from the field. Environmental Science and Pollution Research, 16, 765-794.

Vázquez, S., Goldsbrough, P., \& Carpena, R. O. (2006). Assessing the relative contributions of phytochelatins and the cell wall to cadmium resistance in white lupin. Physiologia Plantarum, 128, 487-495.

Wang, Q., Liang, X., Dong, Y., Xu, L., Zhang, X., Hou, J., \& Fan, Z. (2013). Effects of exogenous nitric oxide on cadmium toxicity, element contents and antioxidative system in perennial ryegrass. Plant Growth Regulation, 69, 11-20.

Wilkins, D. A. (1978). The measurement of tolerance to edaphic factors by means of root growth. New Phytol, 80, 623-633.

Yu, H., Liu, C., Zhu, J., Li, F., Deng, D., Wang, Q., \& Liu, C. (2016). Cadmium availability in rice paddy fields from a mining area: the effects of soil properties highlighting iron fractions and $\mathrm{pH}$ value. Environmental Pollution, 209, 3845.

Publisher's Note Springer Nature remains neutral with regard to jurisdictional claims in published maps and institutional affiliations. 